\title{
Development and application of polymerase chain reaction test for detection of Conidiobolus lamprauges ${ }^{1}$
}

\author{
Marcelo M. Silveira ${ }^{2}$, Daphine A.J. Paula², Maria C. Silva², Leticia C. Pitchenin², \\ Raquel A.S. Cruz ${ }^{3}$, Edson M. Colodel ${ }^{3}$, Valéria Dutra ${ }^{2}$ and Luciano Nakazato ${ }^{2 *}$
}

\begin{abstract}
Silveira M.M., Paula D.A.J., Silva M.C., Pitchenin L.C., Cruz R.A.S., Colodel E.M., Dutra V. \& Nakazato L. 2013. Development and application of polymerase chain reaction test for detection of Conidiobolus lamprauges. Pesquisa Veterinária Brasileira 33(12):14481452. Departamento de Clínica Médica Veterinária, Faculdade de Agronomia, Medicina Veterinária e Zootecnia, Universidade Federal de Mato Grosso, Av. Fernando Corrêa da Costa 2673, Bairro Boa Esperança, Cuiabá, MT 78068-900, Brazil. E-mail: lucnak@ufmt.br

Conidiobolomycosis is a granulomatous disease caused by the fungus Conidiobolus spp. in humans and animals. Traditional technique for diagnosis of the disease is isolation of the agent associated with the presence of typical clinical signs and pathological conditions. The aim of this study was to describe the development of a specific polymerase chain reaction (PCR) test for Conidiobolus lamprauges to detect the fungus in clinical samples. Samples from suspected animals were collected and submitted to isolation, histopathological analysis and amplification by PCR. DNA from tissues was subjected to PCR with fungi universal primers $18 \mathrm{~S}$ rDNA gene, and specific primers were designed based on the same gene in $C$. lamprauges that generated products of about $540 \mathrm{bp}$ and $222 \mathrm{bp}$ respectively. The culture was positive in $26.6 \%$ of clinical samples. The PCR technique for $C$. lamprauges showed amplification of DNA from fresh tissues (80\%) and paraffin sections (44.4\%). In conclusion, the PCR technique described here demonstrated a high sensitivity and specificity for detection of fungal DNA in tissue samples, providing a tool for the rapid diagnosis of $C$. lamprauges.
\end{abstract}

INDEX TERMS: Conidiobolus lamprauges, diagnostic, PCR, sheep, zygomycetes.

RESUMO.- [Desenvolvimento e aplicação da reação em cadeia da polimerase para detecção de Conidiobolus lamprauges.] A conidiobolomicose é uma doença granulomatosa causada pelo fungo Conidiobolus spp., observada em humanos e animais. As técnicas tradicionais de diagnóstico da doença são o isolamento do agente associado à presença de sinais clínicos típicos e condições patológicas. 0 objetivo deste trabalho é descrever o desenvolvimento de um teste da reação em cadeia da polimerase (PCR) específico para Conidiobolus lamprauges em amostras clínicas. As amostras de animais suspeitos foram coletadas e submetidas ao isolamento, análise histopatológica e amplificação pela PCR.

\footnotetext{
${ }^{1}$ Received on August 16, 2013.

Accepted for publication on November 19, 2013.

${ }^{2}$ Laboratório de Microbiologia Veterinária e Biologia Molecular Veterinária, Universidade Federal de Mato Grosso (UFMT), Av. Fernando Corrêa 2673, Coxipó, Cuiabá, MT 78060-900, Brazil. *Corresponding author: lucnak@ufmt.br

${ }^{3}$ Laboratório de Patologia Veterinária, Universidade Federal de Mato Grosso (UFMT), Av. Fernando Corrêa 2673, Coxipó, Cuiabá, MT 78060900, Brazil.
}

O DNA de tecidos foi submetido a PCR com os iniciadores universais de fungos baseados no gene $18 \mathrm{~S}$ rDNA e iniciadores específicos foram concebidos com base no mesmo gene em C. lamprauges que gerou produtos de aproximadamente $540 \mathrm{pb}$ e $222 \mathrm{pb}$, respectivamente. A cultura foi positiva em $26,6 \%$ das amostras clínicas. A técnica de PCR para C. lamprauges mostrou a amplificação de DNA a partir de tecidos frescos (80\%) e secções de parafina (44,4\%). Em conclusão, a técnica de PCR aqui descrita demonstrou elevada sensibilidade e especificidade na detecção de DNA de fungos em amostras de tecido, proporcionando uma ferramenta rápida para o diagnóstico de $C$. lamprauges.

TERMOS DE INDEXAÇÃO: Conidiobolus lamprauges, diagnóstico, PCR, ovinos, zigomicetos.

\section{INTRODUCTION}

Conidiobolomycosis is a disease caused by fungi of the genus Conidiobolus spp., class Zygomycetes of the order Entomophthorales. These saprophytic fungi are opportunistic, associated with granulomatous rhinitis in humans and ani- 
mals (Carrigan et al. 1992, Ribes et al. 2000, Tadano et al. 2005, Hata et al. 2008, Kimura et al. 2011). They are found in soil, decomposing vegetation and as insect parasites (Porto et al. 1987, Scholte et al. 2004, Silva et al. 2007a). This zygomycosis is endemic in tropical regions and in sheep has rapid progression with high lethality (Silva et al. $2007 \mathrm{~b}$ ) and isolates are resistant to mainly antifungal drugs (Tondolo et al. 2013).

Clinically, the animals may show apathy, anorexia, weight loss, swollen nose, granulomatous reaction in the nasopharynx, unilateral exophthalmia, nasal discharge or mucous-serous hemorrhagic, noisy breathing, dyspnea and death (Ketterer et al. 1992, Morris et al. 2001, Riet-Correa et al. 2008, Pedroso et al. 2009, Batista et al. 2009, Silva et al. 2010).

The specie $C$. lamprauges was isolated in samples of sheep in the State of Piauí, Mato Grosso and Santa Catarina, and identified by histopathology and mycological and molecular methods (Silva et al. 2007a, De Paula et al. 2010, Furlan et al. 2010, Vilela et al. 2010).

The objective of this study was to detect rapidly, through the technique of polymerase chain reaction, $C$. lamprauges presence in animal tissue samples, since actual diagnostic techniques based on culture isolation are time consuming with a high rate of false negative results.

\section{MATERIALS AND METHODS}

Isolates and samples. For development of PCR technique, Conidiobolus lamprauges (INCQS 40317) isolate was used as standard. This study tested 15 clinical fresh samples and 18 paraffin embedded tissues samples from sheep with suspected lesions of conidiobolomycosis in the nasal cavity, kidneys, lymph nodes, liver and lungs of sheep between January 2008 to December 2010. Samples were from States of Mato Grosso, Santa Catarina States and Distrito Federal (Brazil).

Isolation. The tissue fragments were washed in sterile saline added with antibiotics (ampicillin $50 \mathrm{mg} / \mathrm{L}$ ), ground with a mortar and pestle and plated on Sabouraud Dextrose Agar plus $0.05 \mathrm{~g} / \mathrm{L}$ of chloramphenicol, and incubated at $30^{\circ} \mathrm{C}$ for 7 days.

Histology. Tissue samples were also formalin solution fixed $10 \%$ routinely processed for histology, stained with hematoxylin-eosin (HE) and the silver-metanamine method (GMS) (Prophet et al. 1992).

DNA extraction. The fresh tissues and isolates of fungi were initially pulverized with liquid nitrogen, ground with a mortar and pestle and then extracted (Doyle \& Doyle 1990). Paraffin embedded tissues was submitted to a deparaffinization process with xilene, followed by DNA extraction method by phenol: chloroform: isoamyl alcohol (Sambrook \& Russel 2001).

Polymerase Chain Reaction (PCR). The extraction products were subjected to PCR with universal primers for fungi, $18 \mathrm{~S}$ ribosomal gene (foward primer: 5'- ATT GGA GGG CAA GTC TGG TG - 3' and reverse primer 5' - CCG ATC CCT AGT CGG CAT AG - 3') (Imhof et al. 2003), and primers specific for $C$. lamprauges (foward primer: 5' - GTG CTG GGG ATA ATC CAT TG - 3' and reverse primer: 5' - CGA CTT TTG CTT TCT CAA GG -3') designed by the program Primer-Blast (http://www.ncbi.nlm.nih.gov) based on 18S ribosomal gene of $C$. lamprauges (GenBank GQ478281.1).

The PCR was carried out with $20 \mu \mathrm{l}$ of final volume, with 10 ng DNA, $2.5 \mathrm{mM} \mathrm{MgCl}_{2}$, 10X Taq Buffer with $50 \mathrm{mM} \mathrm{KCl,} 250 \mu \mathrm{M}$ dNTPs, $1.5 \mathrm{pmol} / \mu \mathrm{l}$ and a primer Taq DNA polymerase $1 \mathrm{U}$ (Fermentas). Ultrapure water was utilized as a negative control.

The PCR was performed using the conditions of $95^{\circ} \mathrm{C}$ for ini- tial denaturation for 3 minutes, followed by 30 cycles of $95^{\circ} \mathrm{C}$ for 20 seconds for denaturation, $54^{\circ} \mathrm{C}$ for 40 seconds for annealing, $72^{\circ} \mathrm{C}$ for 2 minutes for extension, and a final extension step of $72^{\circ} \mathrm{C}$ for 5 minutes. Eight microliters of PCR products were analyzed by electrophoresis on $1 \%$ agarose gel stained with ethidium bromide $(10 \mu \mathrm{g} / \mathrm{mL})$ and observed under UV transiluminator. As a marker of molecular weight standard 100bp DNA Ladder (Fermentas) was used.

Sensibility. The detection limits for the PCR assays were determined by testing serial decimal dilutions plasmid DNA with fragment of $18 \mathrm{~S}$ rDNA. The reaction products of $C$. lamprauges were cloned into a plasmid vector pJET1.2 following the manufacturer's protocol. Escherichia coli (DH5 $\alpha$ ) were transformed and colonies containing inserts were selected using ampicillin. The cloned plasmid was extracted by the Miniprep alkaline lysis protocol (Sambrook \& Russel, 2001) followed by purification in GFX PCR DNA \& Gel Band Purification Kit (GE Healthcare). The quantification of the DNA plasmid (pJet-lamp) was determined by optical density measured by a spectrophotometer and the ratio A260/280. DNA was sequenced using BigDye ${ }^{\circledR}$ Terminator v3.1 Cycle Sequencing Kit and ABI 3500 system.

Specificity. To assess the specificity of the primers in the reaction, we tested samples of $C$. lamprauges (INCQS 40315, INCQS 40316, INCQS 40317, INCQS 40318, INCQS 40319 and INCQS 40320) and other veterinary important fungi, such as Cryptococcus gattii (R265), Aspergillus fumigatus (ATCC 204305), Conidiobolus coronatus (kindly sent by Maria Inez de Moura SarquisFIOCRUZ) and Stramenopila organism, Pythium insidiosum (CBS 101555).

\section{RESULTS}

Samples of fresh tissue and paraffin embedded tissues were tested by PCR with universal primers to fungi and specific primers to Conidiobolus lamprauges. Once the optimal conditions were established with primers for amplification, we obtained products of $540 \mathrm{bp}$ and $222 \mathrm{bp}$ for $18 \mathrm{~S}$ rDNA and C. lamprauges, respectively. There was no amplification of samples from other fungi tested with the primer used for the $C$. lamprauges specificity test (Fig.1). The sensibility of the test based on decimal serial dilutions was detected at
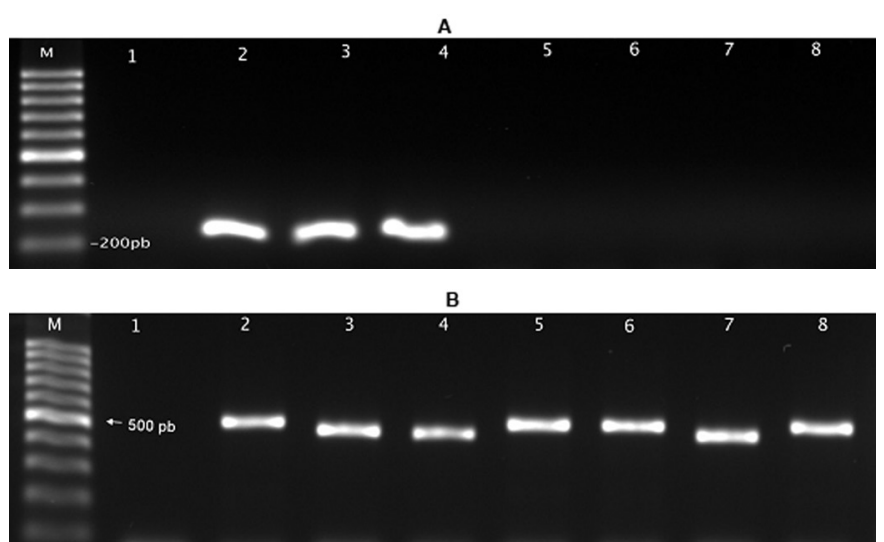

Fig.1. Specificity of PCR assay to Conidiobolus lamprauges on agarose gel electrophoresis (1\%). (A) Specific C. lamprauges primers PCR; (B) 18S rDNA primers PCR. $\mathrm{M}=$ molecular weight marker (Ladder $100 \mathrm{bp}$ ); 1 : negative control; 2: C. lamprauges (INCQS 40315); 3: C. lamprauges (INCQS 40316); 4: C. lamprauges (INCQS 40317); 5: C. coronatus; 6: C. gattii; 7: Aspergillus fumigatus; 8: Pythiuim insidiosum. 


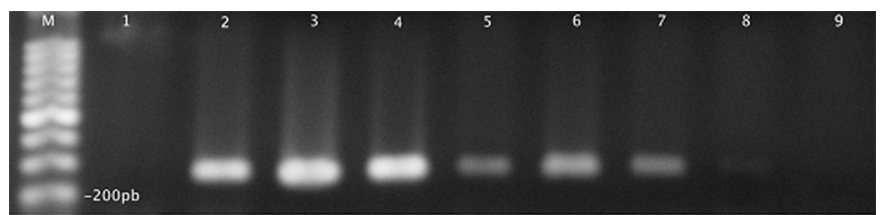

Fig.2. Sensibility of PCR assay to Conidiobolus lamprauges. Agarose gel electrophoresis (1\%) containing products of PCR of serial dilutions of plasmid pJetlamp. $\mathrm{M}=$ molecular weight marker (Ladder $100 \mathrm{bp}$ ). Lane 1 = Negative Control; Lane 2 = Positive Control (500ng/ $\mu \mathrm{l}$ ); Lane $3=3,4 \times 10^{8}$; Lane $4=3,4 \mathrm{x}$ $10^{6}$; Lane $5=3,4 \times 10^{5}$; Lane $6=3,4 \times 10^{4 ;}$ Lane $7=3,4 \times 10^{3}$; Lane $8=3,4 \times 10^{2}$; Lane $9=3,4 \times 10^{1}$ molecules $/ \mu$ l.

the level of $3.4 \times 10^{2}$ molecules of pJet-lamp plasmid in conventional PCR (Fig.2).

From fresh tissue samples tested, $94.4 \%$ were positive for universal fungi $18 \mathrm{~S}$ rDNA gene and $80 \%$ were positive for $C$. lamprauges specific PCR test. The fungal culture was not very efficient, with only $26.6 \%$ of positive samples (Table 1). DNA of $C$. lamprauges was detected in the fragment lesions of the nasopharynx samples $91.6 \%(11 / 12)$, lung $100 \%$ (4/4), lymph nodes $100 \%(1 / 1)$, spleen $50 \%(1 / 2)$ and liver $75 \%(3 / 4)$. Only kidney samples were negative for both universal fungi primers $18 \mathrm{~S}$ rDNA and C. lamprauges test (Table 1). The paraffin tissue samples from archi-

Table 1. Comparison of results of culture isolation with universal and specific PCR for ovine fresh tissues suspected of Conidiobolomycosis from January 2008 to December 2010

\begin{tabular}{|c|c|c|c|c|c|c|c|c|c|c|c|c|c|}
\hline \multirow[t]{2}{*}{ ID } & \multirow[t]{2}{*}{ Culture } & \multicolumn{6}{|c|}{ PCR 18S rDNA } & \multicolumn{6}{|c|}{ PCR C. lamprauges } \\
\hline & & $\mathrm{K}$ & $\mathrm{L}$ & $\mathrm{Li}$ & $\mathrm{LN}$ & $\mathrm{NC}$ & $\mathrm{S}$ & $\mathrm{K}$ & $\mathrm{L}$ & $\mathrm{Li}$ & LN & $\mathrm{NC}$ & $\mathrm{S}$ \\
\hline M764/08 & - & $\bullet$ & $\bullet$ & + & $\bullet$ & $\bullet$ & $\bullet$ & $\bullet$ & $\bullet$ & + & $\bullet$ & $\bullet$ & $\bullet$ \\
\hline M643/08 & - & $\bullet$ & $\bullet$ & + & $\bullet$ & • & - & • & $\bullet$ & + & $\bullet$ & $\bullet$ & $\bullet$ \\
\hline M412/08 & + & $\bullet$ & $\bullet$ & $\bullet$ & $\bullet$ & + & $\bullet$ & $\bullet$ & • & $\bullet$ & $\bullet$ & + & $\bullet$ \\
\hline M90/08 & - & $\bullet$ & $\bullet$ & + & $\bullet$ & + & $\bullet$ & $\bullet$ & $\bullet$ & + & $\bullet$ & - & $\bullet$ \\
\hline M100/08 & - & • & + & $\bullet$ & $\bullet$ & + & • & - & + & $\bullet$ & $\bullet$ & + & $\bullet$ \\
\hline M13/09 & - & $\bullet$ & + & $\bullet$ & + & $\bullet$ & + & • & + & • & + & - & + \\
\hline M86/09 & - & $\bullet$ & $\bullet$ & $\bullet$ & $\bullet$ & - & $\bullet$ & $\bullet$ & $\bullet$ & $\bullet$ & $\bullet$ & - & $\bullet$ \\
\hline M260/09 & + & - & + & - & $\bullet$ & + & - & - & + & - & $\bullet$ & + & - \\
\hline M261/09 & - & $\bullet$ & $\bullet$ & $\bullet$ & $\bullet$ & + & $\bullet$ & $\bullet$ & $\bullet$ & $\bullet$ & $\bullet$ & + & $\bullet$ \\
\hline M614/09 & + & $\bullet$ & $\bullet$ & $\bullet$ & $\bullet$ & + & $\bullet$ & $\bullet$ & $\bullet$ & $\bullet$ & $\bullet$ & + & $\bullet$ \\
\hline M673/09 & - & • & $\bullet$ & $\bullet$ & $\bullet$ & + & $\bullet$ & $\bullet$ & • & $\bullet$ & • & + & $\bullet$ \\
\hline M446/10 & + & $\bullet$ & + & • & - & + & $\bullet$ & $\bullet$ & + & $\bullet$ & - & + & $\bullet$ \\
\hline M447/10 & - & $\bullet$ & • & $\bullet$ & $\bullet$ & + & $\bullet$ & - & $\bullet$ & • & $\bullet$ & + & $\bullet$ \\
\hline M569/09 & - & $\bullet$ & • & $\bullet$ & $\bullet$ & + & $\bullet$ & - & $\bullet$ & - & $\bullet$ & - & $\bullet$ \\
\hline M64/10 & - & $\bullet$ & $\bullet$ & $\bullet$ & $\bullet$ & + & $\bullet$ & $\bullet$ & $\bullet$ & $\bullet$ & $\bullet$ & - & $\bullet$ \\
\hline
\end{tabular}

ID = number identification; $\bullet=$ not available; + = positive; - = negative; NC = nasal cavity; $\mathrm{L}=$ lung. $\mathrm{K}=$ kidney; $\mathrm{LN}=$ head lymph node; $\mathrm{Li}=$ Liver; $\mathrm{S}$ = spleen

val cases had fewer positive cases compared to fresh tissue both to universal fungi $18 \mathrm{~S}$ rDNA and specific C. lamprauges with $44.44 \%$ (8/18) positive samples (Table 2).

Histopathologically, all specimens contained multifocal granulomatous inflammation characterized by moderate connective tissue proliferation and infiltration of macrophages, epithelioid cells and multinucleated giant cells surrounding necrotic areas containing eosinophilic material (Splendore-phenomenon Hoeplli), coenocytic hyphae with numerous, often dilated, globular terminals which im-
Table 2. Comparison results of $18 \mathrm{~S}$ rDNA and Conidiobolus lamprauges PCR for ovine paraffin embedded tissues suspected of Conidiobolomycosis from 2007 to December 2010

\begin{tabular}{lccc}
\hline ID & 18 S & C. lamprauges & Histology \\
\hline N 120/07 & + & + & + \\
N 27963 & - & - & + \\
CAU 28036 & - & - & + \\
CAU 27919 & - & - & + \\
N 27948 & + & + & + \\
27869 & - & - & + \\
N 128/07 & + & + & + \\
N 78/07 & + & + & + \\
N 119/07 & + & + & + \\
N 71/07 & - & - & + \\
N 202/08 & + & + & + \\
N 152/06 & + & + & + \\
N 138/07 & - & - & + \\
M 13/09 & - & - & + \\
M 90/08 & - & - & + \\
N 104/07 & - & - & + \\
M 100/08 & + & + & + \\
N 104/07B & - & - & + \\
& & & +
\end{tabular}

pregnated in silver-metanamine method staining and were compatible with zygomycetes hyphae.

\section{DISCUSSION}

The diagnosis of ovine zygomycosis is based in the isolation of the agent associated with epidemiological aspects and the presence of clinical signs and pathological change, however, the fungal culture is time consuming and may be associated with false negative results, due to the possible of secondary contaminants during isolation which lower sensitivity and specificity of the test. Another problem is morphological classification based on microscopic structures of the fungi that is similar to the other zygomycetes or Conidiobolus species (Kaufman et al. 1990, Ribes et al. 2000, Imhof et al. 2003, Silva et al. 2007a, 2007b, Hata et al. 2008, De Paula et al. 2010).

The PCR test primers should be employed with sufficient counterparts to allow amplification of target DNA, allowing the specific detection of the desired organism. Some impurities in the DNA sample can inhibit the reaction, and it is recommended that primers that recognize a universal gene are included (Schmitz et al. 2010). In this study, we used universal primers of 18S rDNA region (Imhof et al. 2003) and primers specific for C. lamprauges and its specificity was $100 \%$.

In this study $26.6 \%$ of fresh samples were positive in culture. The findings show the difficulty of isolating the agent in clinical samples, however it is similar to other studies (Silva et al. 2007a, Hata et al. 2008). Traditional techniques for identification of fungi such as cultivation can detect only the presence of viable cells, and in contrast, the PCR can be a sensitive and specific form to detect these microorganisms, even those non-viable (Schmitz et al. 2010).

Universal fungi primers and specific Conidiobolus lamprauges PCR tests detected the presence of infection by $C$. lamprauges in more cases when compared to culture isola- 
tion in fresh tissue. Only one case (M86/09) was negative to both tests despite the presence of compatible lesions at histopathological observation. In this case, occurrence of Pythium insidiosum should be considered since the disease can affect the nasal cavity of ovine (Santurio et al. 2008, Ubiali et al. 2013).

Diagnosis of archival cases based on paraffin embedded tissue were reached but with lower positive cases. Only one case was positive in paraffin embedded tissue from three samples positive in fresh tissues. This could be associated to damage to DNA of this tissue due to longer incubation period in formalin during the fixing protocol (Dubeau et al. 1986).

There are description of treatments no-success of conidiobolomycosis in sheep (Ribes et al. 2000, Silva et al. 2007b, Boabaid et al. 2008, Portela et al. 2010). The difficulty in diagnosis and the rapid course of illness may contribute to high mortality rates (Silva et al. 2007b). This can happen because of positive and painless lesions with present signs of disease only when it is already in an advanced stage (Riet-Correa et al. 2008) and its early diagnosis is very important to establish the appropriate therapy (Herrera et al. 2009, Portela et al. 2010). In this context, the use of diagnostic methods that are reliable and fast are necessary to improve survival rate of infected animals (Herrera et al. 2009).

Due to its specificity and sensitivity, PCR is an important alternative method for the diagnosis of various species of fungi, without the requirement of prior fungal isolation. Highly conserved regions and specific genes such fungi, as the 18S rDNA gene is used because it is repeated dozen of times in the fungal genome (Imhof et al. 2003, Herrera et al. 2009).

\section{CONCLUSION}

The PCR technique developed showed high sensitivity and specificity for detection of Conidiobolus lamprauges in tissue samples and becomes a tool for rapid diagnosis for infection.

Acknowledgments.- To the Research Support Foundation of Mato Grosso (FAPEMAT) for financial support to conduct this work, and to the National Council for Scientific and Technological Development (CNPq) for scholarship.

\section{REFERENCES}

Batista M., Castro R., Rego E., Carvalho F., Silva S., Carvalho C. \& Riet-Correa F. 2009. Hemograma, proteinograma, ionograma e dosagens bioquímicas e enzimáticas de ovinos acometidos por conidiobolomicose no Nordeste do Brasil. Pesq. Vet. Bras. 29:17-24.

Boabaid F.M., Ferreira E.V., Arruda L.P., Gasparetto N.D., Souza R.L., Silva M.C., Dutra V., Nakazato L. \& Colodel E.M. 2008. Conidiobolomicose em ovinos no Estado de Mato Grosso. Pesq. Vet. Bras. 28:77-81.

Carrigan M., Small A. \& Perry G. 1992. Ovine nasal zygomycosis caused by Conidiobolus incongruus. Aust. Vet. J. 69:237-240.

De Paula D.A.J., Oliveira Filho J.X., Silva M.C., Colodel E.M., Broetto L., Pinto P.M., Schrank A., Nakazato L. \& Dutra V. 2010. Molecular characterization of ovine zygomycosis in central western Brazil. J. Vet. Diagn. Invest. 22:274-277.

Doyle J.J. \& Doyle J.L. 1990. A rapid DNA isolation procedure for small quantities of fresh leaf tissue. Phytochem. Bull. 19:11-15.
Dubeau L., Chandler L.A., Gralow J.R., Nichols P.W.\&Jones P.A.1986. Southern blot analysis of DNA extracted from formalin-fixed pathology specimens. Cancer Res. 46(6):2964-2969.

Furlan F.H., Lucioli J., Veronezi L.O., Fonteque J.H., Traverso S.D., Nakazato L. \& Gava A. 2010. Conidiobolomicose causada por Conidiobolus lamprauges em ovinos no Estado de Santa Catarina. Pesq. Vet. Bras. 30(7):529-532.

Hata D., Buckwalter S., Pritt B., Roberts G. \& Wengenack N. 2008. Real-time PCR method for detection of zygomycetes. J. Clin. Microbiol. 46:23532358.

Herrera M.L., Vallor A.C., Gelfond J.A., Patterson T.F. \& Wickes B.L. 2009. Strain-dependent variation in $18 \mathrm{~S}$ ribossomal DNA copy numbers in $\mathrm{As}^{-}$ pergillus fumigatus. J. Clin. Microbiol. 47(5):1325-1332.

Imhof A., Schaer C., Schoedon G., Schaer D., Walter R., Schaffner A. \& Schneemann M. 2003. Rapid detection of pathogenic fungi from clinical specimens using Light Cycler real-time fluorescence PCR. Eur. J. Clin. Microbiol. Infect. Dis. 22:558-560.

Kaufman L., Mendoza L. \& Standard P. 1990. Immunodiffusion test for serodiagnosing subcutaneous zygomycosis. J. Clin. Microbiol. 28:18871890.

Ketterer P., Kelly M., Connole M. \& Ajello L. 1992. Rhinocerebral and nasal zygomycosis in sheep caused by Conidiobolus incongruus. Aust. Vet. J. 69:85-87.

Kimura M., Yaquchi T., Sutton D.A., Fothergill A.W., Thompson E.H. \& Wickes B.L. 2011. Disseminated human connidiobolomycosis due to Conidiobolus lamprauges. J. Clin. Microbiol. 49:752-756.

Morris M., Ngeleka M., Adogwa A.O., Lalla G., St-Germanin G. \& Higgins R. 2001. Rhinocerebral zygomycosis in a sheep. Can. Vet. J. 42:227-228.

Pedroso P., Raymundo D., Bezerra J., Oliveira E., Sonne L., Dalto A. \& Driemeier D. 2009. Rinite micótica rinofaríngea em um ovino Texel no Rio Grande do Sul. Acta Scient. Vet. 37:181-185.

Portela R.A., Riet-Correa F., Junior F.G., Dantas A.F.M., Simões S.V.D. \& Silva S.M.S. 2010. Doenças da cavidade nasal em ruminantes no Brasil. Pesq. Vet. Bras. 30:844-854.

Porto E., Melo N.T., Heins-Vaccari E.M., Lacaz C.S. \& Assis C.M. 1987. Isolamento de Conidiobolus coronatus (Costantin) Batko, 1964, de amostras de terra com e sem detritos vegetais. An. Bras. Dermatol. 62(5/6):303-307.

Prophet E.B., Mills B., Arrington J.B. \& Sobin L.H. 1992. Laboratory Methods in Histotechnology. Armed Forces Institute of Pathology, Washington. $279 \mathrm{p}$.

Ribes J., Vanover-Sams C. \& Baker D. 2000. Zygomycetes in human disease. Clin. Microbiol. Rev. 13:236-301.

Riet-Correa F., Dantas A.F.M., Azevedo E.O., Simões S.D.V., Silva S.M.M.S., Vilela R. \& Mendoza L. 2008. Outbreaks of rhinofacial and rhinopharyngeal zygomycosis in sheep in Paraíba, northeastern Brazil. Pesq. Vet. Bras. 28:29-35.

Sambrook J. \& Russel D.W. 2001. Molecular Cloning: A Laboratory Manual. Vol.1-3. Cold Spring Harbor Laboratory Press, New York. 2231p.

Santurio M.J., Argenta J.S., Schwendler S.E., Cavalheiro A.S., Pereira D.I.B., Zanette R.A., Alves S.H., Dutra V., Silva M.C., Arruda L.P., Nakazato L. \& Colodel E.M. 2008. Granulomatous rhinitis associated with Pythium insidiosum infection in sheep. Vet. Rec. 163:276-277.

Schmitz R.P.H., Eck R. \& Lehmann M. 2010. New approaches in fungal DNA preparation from whole blood and subsequent pathogen detection via multiplex PCR, p.317-335. In: Youssuf G. \& Kerstin V. (Eds), Molecular Identification of Fungi. Springer, New York.

Scholte E.J., Knols B.G.J., Samson R.A. \& Takken W. 2004. Entomopathogenic fungi for mosquito control: a review. J. Insect Sci. 4(19):1-46.

Silva S.M.M.S., Castro R., Costa F., Vasconcelos A., Batista M., Riet-Correa F. \& Carvalho E.M.S. 2007a. Conidiobolomycosis in sheep in Brazil. Vet. Pathol. 44:314-319.

Silva S.M.M.S., Castro S., Costa F., Vasconcelos A., Batista M., Riet-Correa F., Carvalho E.M.S. \& Lopes J.B. 2007b. Epidemiologia e sinais clínicos da conidiobolomicose em ovinos no Estado do Piauí. Pesq. Vet. Bras. 27:184-190. 
Silva S.M.M.S., Ferreira L.H., Souza F.A.L., Nascimento E.F., Costa E.A., Paixão T.A. \& Santos R.L. 2010. Conidiobolomicose em ovinos: reavaliação de três casos previamente diagnosticados como tumor etmoidal enzoótico. Arq. Bras. Med. Vet. Zootec. 62(6):1503-1506.

Tadano T., Paim N., Hueb M. \& Fontes C. 2005. Entomophthoramycosis (zygomycosis) caused by Conidiobolus coronatus in Mato Grosso, Brazil: case report. Revta Soc. Bras. Med. Trop. 38:188-190.

Tondolo J.S.M., Loreto E.S., Dutra v., Nakazato L., Paula D.A.J., Zanette R.A., Santurio J.M. 2013. In vitro susceptibility of Conidiobolus lam- prauges recovered from sheep to antifungal agents. Vet Microbiology. 166: 690-693.

Ubiali D.G., Cruz R.A.S., Paula D.A.J., Silva M.C., Mendonça F.S., Dutra V., Nakazato L., Colodel E.M. \& Pescador C.A. 2013. Pathology of nasal infection caused by Conidiobolus lamprauges and Pythium insidiosum in sheep. J. Comp. Pathol. 149(2/3):137-145.

Vilela R., Silva S.M.S., Riet-Correa F., Dominguez E. \& Mendoza L. 2010. Morphologic and phylogenetic characterization of Conidiobolus lamprauges recovered from infected sheep. J. Clin. Microbiol. 48(2):427-432. 